\title{
Efektivitas Permen Karet Xylitol dalam Menurunkan Plak
}

\author{
Baban Saputera, Dinar A. Wicaksono, Johanna A. Khoman
}

Program Studi Pendidikan Dokter Gigi Fakultas Kedokteran, Manado, Universitas Sam Ratulangi, Manado

Email: babansaputera@gmail.com

\begin{abstract}
Oral and tooth problem that often occurs is caries worldwide. According to Riset Kesehatan Dasar (Baseline Health Research) in 2018, the largest proportion of oral and tooth problems in Indonesia is caries $(45,3 \%)$. Caries could be caused inter alia by the presence of bacterial accumulation attached to plaque. One of the ways to control plaque is xylitol chewing gum which is proven to be quite effective in cleaning teeth from debris and plaque, preventing periodontal diseases, increasing salivary $\mathrm{pH}$, and stimulating saliva excretion. This study was aimed to evaluate the effectiveness of xylitol chewing gum in reducing plaque. This was a literature review study using two databases, namely Google Scholar and Indonesia One Search. The results showed that samples used in the literatures were 10-24 years old. The xylitol doses used were $3.4 \mathrm{~g} /$ day, $4.05 \mathrm{~g} /$ day, $6 \mathrm{~g} /$ day, and $45 \mathrm{~g} /$ day. Xylitol dose below $3.4 \mathrm{~g} / \mathrm{day}$ was not effective and dose above $10 \mathrm{~g} /$ day was less effective to reduce $S$. mutans. In conclusion, xylitol chewing gum at a dose of $3.4 \mathrm{~g}-10 \mathrm{~g}$ per day is quite effective in reducing plaque.
\end{abstract}

Keywords: xylitol chewing gum; dental plaque

\begin{abstract}
Abstrak: Masalah kesehatan gigi dan mulut khususnya karies merupakan penyakit yang dialami oleh sebagian besar penduduk di dunia. Riset Kesehatan Dasar (RISKESDAS) pada tahun 2018 menyatakan bahwa proporsi terbesar masalah gigi dan mulut di Indonesia ialah karies $(45,3 \%)$. Penyebab terjadinya karies ialah antara lain adanya kumpulan bakteri yang terikat dalam plak. Salah satu pengendalian plak ialah dengan tindakan mengunyah permen karet xylitol yang terbukti cukup efektif membersihkan gigi dari debris dan plak, mencegah terjadinya penyakit periodontal, meningkatkan $\mathrm{pH}$ saliva, dan merangsang pengeluaran saliva. Penelitian ini bertujuan untuk mengulas efektivitas permen karet xylitol dalam menurunkan plak. Jenis penelitian ialah literature review dengan menggunakan dua database yaitu Google Scholar dan Indonesia One Search. Hasil penelitian mendapatkan bahwa kelompok eksperimen penelitian yang dikaji berkisar 10-24 tahun. Dosis xylitol yang dipakai dalam penelitian berkisar 3,4 gr/hari, 4,05 gr, 6 gr/hari, dan 45 gr per hari. Dosis xylitol di bawah 3,4 gr/hari tidak efektif dan dosis yang melebihi $10 \mathrm{gr} / \mathrm{hari}$ juga kurang efektif terhadap reduksi S. mutans. Simpulan penelitian ini ialah mengunyah permen karet xylitol dengan dosis 3,4 gr-10 gr per hari cukup efektif dalam menurunkan plak.
\end{abstract}

Kata kunci: permen karet xylitol; plak

\section{PENDAHULUAN}

Kondisi seseorang dalam keadaan sehat fisik, mental, spritual, maupun sosial agar dapat menjalani hidup secara baik merupakan definisi kesehatan menurut Kementrian Kesehatan RI. ${ }^{1}$ Menurut Malik, yang perlu diperhatikan selain kesehatan tubuh secara umum yaitu kesehatan gigi dan mulut. Hal tersebut dikarenakan kesehatan gigi dan mulut menjadi salah satu bagian tubuh terpenting sebagai tempat jalan masuknya makanan. Dengan demikian kesehatan gigi dan mulut tidak dapat dipisahkan dari kesehatan tubuh secara umum. ${ }^{2}$

Menurut Bahan Kesehatan Dunia (World Health Organization), masalah kese- 
hatan gigi dan mulut disebabkan oleh karies dan penyakit periodontal. ${ }^{3}$ Data dari The Global Burden of Disease Study 2016 menyatakan bahwa masalah yang berhubungan dengan kesehatan gigi dan mulut khususnya karies merupakan penyakit yang dialami oleh sebagian besar penduduk di dunia (3,58 milyar jiwa). Hal tersebut diperkuat oleh hasil Riset Kesehatan Dasar (RISKESDAS) tahun 2018 bahwa proporsi terbesar masalah gigi dan mulut di Indonesia ialah karies $(45,3 \%){ }^{4}$

Karies adalah penyakit jaringan keras gigi yang meliputi email, dentin, dan sementum yang disebabkan oleh menumpuknya mikroorganisme antara lain bakteri Actinomyces, Lactobacilli, dan berbagai jenis Streptococcus (Streptococcus oralis, Streptococcus mitis, Streptococcus anginosus, Streptococcus mutans). Namun jenis bakteri yang paling dominan dalam terjadinya karies yaitu Streptococcus mutans. Faktor terjadinya karies bukan karena mikroorganisme saja tetapi antara lain oleh pejamu (gigi), substrat (makanan) serta waktu. Selain itu terdapat faktor lainnya seperti pengalaman karies, sosial ekonomi, usia, jenis kelamin, geografis, serta perilaku kesehatan individu terhadap gigi dan mulut. ${ }^{5,6}$

Salah satu penyebab karies ialah adanya kumpulan bakteri yang terikat dalam plak yang tidak bisa dihindari. ${ }^{7,8}$ Usaha pengendalian plak dapat ditempuh melalui dua cara yaitu secara mekanis dan kimiawi yang telah dibuktikan pada berbagai literatur. Cara mekanis yaitu dengan menggunakan sikat gigi sedangkan cara kimiawi yaitu dengan menggunakan bahan kimia yang bersifat anti plak seperti pasta gigi, obat kumur. dan permen karet xylitol. Mengunyah permen karet xylitol merupakan salah satu alternatif yang telah terbukti cukup efektif untuk membersihkan gigi dari debris dan plak, mencegah terjadinya penyakit periodontal, meningkatkan $\mathrm{pH}$ saliva, dan merangsang pengeluaran saliva. ${ }^{9-12}$

Tindakan pengendalian plak yang mudah dilakukan ialah dengan mengunyah permen karet xylitol. Manfaat mengunyah permen karet xylitol lebih mudah diperoleh dibandingkan harus menyikat gigi dan menggunakan obat kumur yang perlu dilakukan di tempat khusus. Permen karet xylitol dapat dikunyah saat hangout, dan mudah didapatkan misalnya di supermarket. Selain itu, dewasa ini banyak orang yang menyukai permen karet xylitol karena tersedia dengan berbagai rasa. Berdasarkan latar belakang yang telah dikemukakan maka penulis tertarik untuk mengulas efektivitas permen karet xylitol dalam menurunkan plak.

\section{METODE PENELITIAN}

Penelitian ini merupakan suatu literature review. Data yang digunakan dalam penelitian ini ialah data sekunder yang diperoleh dengan menggunakan dua database yaitu Google Scholar dan Indonesia One Search. Kata kunci yang digunakan dalam pencarian jurnal yaitu permen karet xylitol dan plak. Kriteria inklusi penelitian ini ialah literatur terbitan tahun 2010-2020, berbahasa Indonesia, dan adanya sampel penelitian yang mengunyah permen karet xylitol dalam menurunkan plak.

\section{HASIL PENELITIAN}

Berdasarkan hasil pencarian literatur yang disaring dari tahun 2010-2020 dengan kata kunci (permen karet xylitol, plak) pada database Google Scholar dan Indonesia One Search, didapatkan sebanyak 130 lite-ratur menggunakan Google Scholar dan enam literatur menggunakan Indonesia One Search $(n=136)$. Hasil pencarian dilanjutkan dengan penyaringan berdasarkan judul dan abstrak yang sesuai dengan topik bahasan, dan didapatkan 18 literatur dari Google Scholar dan empat literatur dari Indonesia One Search $(\mathrm{n}=22)$. Selanjutnya literatur disaring kembali berdasarkan kriteria inklusi, dan didapatkan enam literatur dari database Google Scholar dan satu literatur dari Indonesia One Search $(\mathrm{n}=7)$.

Tabel 1 memperlihatkan hasil pencarian literatur yang diuraikan berdasarkan peneliti, tahun publikasi, judul literatur, serta metode penelitian dan sampel yang digunakan. 
Tabel 1. Hasil pencarian literatur

\begin{tabular}{|c|c|c|}
\hline $\begin{array}{c}\text { Peneliti dan } \\
\text { Tahun }\end{array}$ & Judul & $\begin{array}{c}\text { Metode dan } \\
\text { Sampel }\end{array}$ \\
\hline $\begin{array}{l}\text { Fatikarini I, } \\
\text { Handajani I, } \\
\text { 2011.13 }\end{array}$ & $\begin{array}{l}\text { Pengunyahan permen karet gula dan xylitol menurunkan } \\
\text { pembentukan plak gigi }\end{array}$ & $\begin{array}{l}\text { Eksperimental } \\
\text { Usia 18-24 tahun }\end{array}$ \\
\hline $\begin{array}{l}\text { Rahmawati DY, } \\
2011 . .^{4}\end{array}$ & $\begin{array}{l}\text { Efektivitas mengunyah permen karet berxylitol untuk } \\
\text { mengurangi indeks plak gigi (studi kasus di SDN Sekaran } \\
01 \text { Gunungpati Semarang) }\end{array}$ & $\begin{array}{l}\text { Eksperimental } \\
\text { Usia } 10-13 \text { tahun }\end{array}$ \\
\hline $\begin{array}{l}\text { Kusumaningsari } \\
\text { V, Handajani J, } \\
\text { 2011.15 }\end{array}$ & $\begin{array}{l}\text { Efek pengunyahan permen karet gula dan xylitol terhadap } \\
\text { pertumbuhan bakteri Streptococcus mutans pada plak gigi }\end{array}$ & $\begin{array}{l}\text { Eksperimental } \\
\text { Usia 18-24 tahun }\end{array}$ \\
\hline $\begin{array}{l}\text { Sumantri D, } \\
2013 .{ }^{16}\end{array}$ & $\begin{array}{l}\text { Pengurangan akumulasi plak gigi dengan membandingkan } \\
\text { metode mengunyah permen karet xylitol dan berkumur teh } \\
\text { hijau }\end{array}$ & $\begin{array}{l}\text { Eksperimental } \\
\text { Usia } 12-13 \text { tahun }\end{array}$ \\
\hline $\begin{array}{l}\text { Elina L, } \\
\text { Wahyuni S, } \\
\text { 2017.17 }\end{array}$ & $\begin{array}{l}\text { Pengaruh pengunyahan permen karet yang mengandung } \\
\text { sukrosa dan permen karet yang mengandung xylitol } \\
\text { terhadap indeks plak gigi }\end{array}$ & $\begin{array}{l}\text { Eksperimental } \\
\text { Usia } 11-12 \text { tahun }\end{array}$ \\
\hline $\begin{array}{l}\text { Hasibuan UHR, } \\
2018 .^{18}\end{array}$ & $\begin{array}{l}\text { Gambaran mengunyah permen karet yang mengandung } \\
\text { xylitol dalam menurunkan indeks plak pada siswa/i kelas V } \\
\text { SD Negeri } 0507 \text { Latong Kecamatan Lubuk Barumun } \\
\text { Kabupaten Padang Lawas }\end{array}$ & $\begin{array}{l}\text { Deskriptif dengan } \\
\text { metode survei. } \\
30 \text { siswa/i }\end{array}$ \\
\hline $\begin{array}{l}\text { Nabila NN, } \\
2019 .{ }^{19}\end{array}$ & $\begin{array}{l}\text { Pengaruh mengunyah permen karet yang mengandung } \\
\text { xylitol terhadap pH saliva dan indeks plak pada siswa SLB } \\
\text { A (Tunanetra) Negeri Semarang tahun } 2019\end{array}$ & $\begin{array}{l}\text { Eksperimental } \\
27 \text { anak }\end{array}$ \\
\hline
\end{tabular}

Penelitian pertama yang dilakukan Fatikarini dan Handajani ${ }^{13}$ mendapatkan bahwa mengunyah permen karet xylitol dan gula selama tujuh hari dapat menurunkan pembentukan plak. Mengunyah permen karet xylitol dapat menurunkan plak karena xylitol tidak dapat difermentasikan oleh bakteri plak sehingga meningkatkan fungsi buffer saliva yang selanjutnya memperlambat akumulasi plak serta berperan sebagai antibakteri. Mengunyah permen gula juga dapat memperlambat pertumbuhan plak karena dapat merangsang meningkatnya saliva. Glukosa yang terkandung pada permen gula tidak menyebabkan akumulasi plak karena di saat bersamaan kadar saliva meningkat yang nantinya berpengaruh menurunkan plak.

Penelitian kedua yang dilakukan Rahmawati $^{14}$ mendapatkan penurunan skor indeks plak bagi yang mengunyah permen karet xylitol, sedangkan yang tidak mengunyah permen karet xylitol mengalami kenaikan skor indeks plak. Nilai p pada kelompok eksperimen tahap pertama yaitu 0,001 dan kelompok eksperimen tahap kedua yaitu 0,000 , yang berarti terdapat perbedaan antara skor indeks plak antara sebelum dan sesudah mengunyah permen karet xylitol yang membuktikan permen karet xylitol efektif dalam menurunkan skor indeks plak. Skor indeks plak bagi yang mengunyah permen karet tidak berxylitol memperoleh nilai $p$ eksperimen tahap pertama yaitu 0,000 dan eksperimen tahap kedua yaitu 0,001 . Hal ini menunjukkan terdapatnya perbedaan antara skor indeks plak sebelum dan sesudah mengunyah permen karet tidak berxylitol yang dapat meningkatkan skor indeks plak.

Penelitian ketiga yang dilakukan Kusumaningsari dan Handajani ${ }^{15}$ mendapatkan adanya perbedaan jumlah bakteri $S$. mutans antara yang mengunyah permen karet xylitol dan permen karet gula. Permen karet gula dapat memicu kenaikan jumlah bakteri $S$. mutans dikarenakan gula dengan mudah dapat dimetabolisir menjadi energi oleh $S$. mutans dan juga memicu perkembangan bakteri $S$. mutans. Hasil metabolisme glukosa mempunyai sifat asam yakni asam laktat, asam asetat, dan asam format yang dapat menurunkan $\mathrm{pH}$ plak dalam kurun waktu 1-3 menit sehingga mencapai 
$\mathrm{pH}$ 4,5-5,0. Pada $\mathrm{pH}$ ini bakteri $S$. mutans akan berkembang biak lebih cepat karena sifatnya asidurik dan asinogenik. Mengunyah permen karet xylitol dapat memicu penurunan jumlah bakteri $S$. mutans karena xylitol merupakan jenis gula alkohol yang berifat antibakteri dan tidak dapat dimetabolisir oleh bakteri $S$. mutans untuk menjadi energi. Bakteri $S$. mutans akan berusaha memetabolisir xylitol namun tidak menghasilkan energi sehingga akhirnya bakteri tersebut akan kehabisan energi dan kemudian mati yang ditandai dengan terjadinya penurunan jumlah bakteri $S$. mutans pada plak yang dikenal sebagai siklus fulite. ${ }^{15}$

Penelitian keempat yang dilakukan Sumantri ${ }^{16}$ mendapatkan bahwa pada kelompok pertama penelitian yang mengunyah permen karet xylitol, rerata skor indeks plak sebelum perlakuan yaitu 1,212. Kemudian diberi perlakuan mengunyah permen karet xylitol selama 5 menit pada semua regio gigi dan didapatkan rerata skor indeks plak sesudah perlakuan turun menjadi 0,631. Hal ini membuktikan bahwa mengunyah permen karet xylitol dapat menurunkan skor indeks plak. Hasil pada kelompok kedua penelitian yang berkumur dengan teh hijau memperlihatkan rerata skor indeks plak sebelum perlakuan yaitu 1,575, kemudian diberi perlakuan berkumur teh hijau dengan kencang dan bersuara selama 30 detik, didapatkan rerata skor indeks plak sesudah perlakuan turun menjadi 1,134. Dengan membandingkan mengunyah permen karet xylitol dan berkumur teh hijau, dapat disimpulkan bahwa permen karet xylitol mempunyai persentase pengurangan plak yang lebih besar.

Penelitian kelima yang dilakukan Elina dan Wahyuni ${ }^{17}$ mendapatkan bahwa hasil mengunyah permen karet xylitol dan permen karet sukrosa mampu menurunkan indeks plak dikarenakan mengunyah permen karet sifatnya melekat erat. Dengan membersihkan sisa makanan pada permukaan gigi dan meningkatkan produksi saliva yang dapat membersihkan isi mulut maka hal tersebut akan mengurangi potensi terjadinya plak. Pada uji pertama dengan Anova didapatkan rerata indeks plak dengan sukrosa 1,3278 sedangkan dengan xylitol 1,0155. Hal ini berarti bahwa permen karet xylitol lebih efektif daripada permen karet sukrosa karena xylitol tidak dapat difermentasi oleh bakteri plak. Juga aliran saliva yang dirangsang dari mengunyah permen karet xylitol dapat memicu peningkatan buffer saliva yang dapat menghambat akumulasi plak. Selain itu permen karet xylitol juga berfungsi sebagai antibakteri.

Penelitian keenam yang dilakukan Hasibuan ${ }^{18}$ mendapatka hasil rerata indeks plak sebelum mengunyah permen karet xylitol sebesar 1,4 dengan kriteria sedang, sedangkan rerata sesudah mengunyah permen karet xylitol sebesar 0,4 dengan kriteria baik, dan diperoleh rerata penurunan indeks plak sebesar 1 dengan kriteria baik. Xylitol merupakan sejenis gula alternatif golongan polialkohol yang mampu memperlambat pertumbuhan bakteri pembentuk plak. Xylitol juga dapat menghambat sintesis polisakarida ekstrasel yang mengakibatkan perlekatan bakteri penyebab plak. Dengan kata lain permen karet xylitol efektif untuk menurunkan indeks plak.

Penelitian ketujuh yang dilakukan Nabila $^{19}$ menunjukkan nilai pretest rerata kelompok eksperimen terhadap saliva sebesar 6,52 dan nilai rerata post-test 6,90. Terjadinya peningkatan 0,45 dikarenakan mengunyah permen karet xylitol akan menstimulasikan sekresi saliva serta meningkatkan buffering dan $\mathrm{pH}$ saliva. Selanjutnya pada kelompok eksperimen terhadap indeks plak diperoleh nilai rerata pre-test sebesar 7,03 dan nilai rerata post-test sebesar 6,90. Terjadinya penurunan 0,42 dikarenakan xylitol dapat mengikat molekul sukrosa dengan S. mutans, sehingga xylitol tidak dapat difermentasi oleh Streptoccocus mutans. Mengunyah permen karet xylitol dianjurkan setelah makan yang mengandung karbohidrat sebanyak 1-2 gram dan sampai 5 kali sehari selama 5 menit.

\section{BAHASAN}

Hasil penelitian literatur yang dikaji menunjukkan adanya penurunan plak dengan perlakuan mengunyah permen karet 
xylitol. Penelitian terhadap seluruh subjek dilakukkan sebelum dan sesudah perlakuan. Subjek penelitian dilarang melakukan tindakan kebersihan gigi dan mulut sebagai rentang waktu proses terjadinya plak. Pada masa pembentukan plak di area permukaan gigi, diberikan perlakuan yang kemudian diamati pengaruh perlakuan terhadap akumulasi plak.

Penelitian yang dilakukan Fatikarini dan Handajani ${ }^{13}$ menunjukkan adanya penurunan indeks plak pada kelompok eksperimen yang mengunyah permen karet xylitol. Hal tersebut sejalan dengan penelitian oleh Rahmawati ${ }^{14}$ yang melaporkan adanya penurunan plak setelah mengunyah permen karet xylitol. Selanjutnya penelitian yang dilakukan Sumantri ${ }^{16}$ menunjukkan adanya penurunan akumulasi plak yang lebih besar pada kelompok eksperimen yang mengunyah permen karet xylitol. Elina dan Wahyuni ${ }^{17}$ melaporkan adanya penurunan indeks plak yang efektif pada kelompok eksperimen yang mengunyah permen karet xylitol. Hal tersebut sejalan dengan penelitian oleh Hasibuan ${ }^{18}$ dan oleh Nabila ${ }^{19}$ yang menunjukkan adanya penurunan indeks plak pada kelompok yang mengunyah permen karet xylitol.

Penelitian lainnya menyebutkan bahwa xylitol dapat mengurangi akumulasi plak. Hasil penelitian dari Scheinin (1971) dan Makinen (1972) menyatakan bahwa mengunyah permen karet xylitol selama empat hari bisa mengurangi 50\% akumulasi plak serta mengurangi tingkat karies $85 \%$. Umumnya sebagian besar plak terdiri dari koloni bakteri Streptococcus yaitu Streptococcus mitis, Streptococcus oralis, Streptococcus sanguis, dan paling banyak ialah Streptococcus mutans. ${ }^{20}$ Permen karet xylitol mempunyai efek mengurangi pelekatan bakteri $S$. mutans yang berkaitan langsung dengan kerusakan pada gigi. Xylitol dapat mengurangi kemampuan bakteri untuk melekat pada email dengan memengaruhi metabolisme bakteri dan kemampuannya dalam membentuk kapsul-kapsul dalam plak bakteri. Hal tersebut memberi kesempatan kepada mulut untuk melakukan remineralisasi pada gigi berlubang tanpa adanya gangguan. ${ }^{21}$ Penelitian-penelitian yang telah dilaporkan sejalan dengan penelitian yang dilakukkan yang menyebutkan permen karet xylitol bersifat antibakteri. ${ }^{15}$

Dari hasil penelitian yang dikaji, didapatkan kelompok eksperimen pada usia 10-24 tahun. Dosis xylitol yang dianjurkan dalam penelitian oleh Autio dan Courts ${ }^{22}$ ialah 4,05 gr ( $3 \times 1,35$ gr). Pada penelitian yang dilakukan Kandelman dan Gagnon ${ }^{23}$ digunakan dosis xylitol sebesar 3,4 gr/hari. Literatur lain menyatakan dosis mengunyah permen karet xylitol agar mendapatkan aksi protektif ialah $6 \mathrm{gr} / \mathrm{hari}{ }^{24}$ Menurut Akerblom et $\mathrm{al}^{25}$ anak-anak dapat bertoleransi dengan dosis hingga 45 gr tanpa adanya efek samping. Ly et $\mathrm{al}^{26}$ menyatakan dosis xylitol dibawah 3,4 gr/hari tidak efektif dan dosis yang melebihi $10 \mathrm{gr} /$ hari juga kurang efektif terhadap reduksi $S$. mutans.

\section{SIMPULAN}

Mengunyah permen karet xylitol dengan dosis 3,4-10 gr per hari cukup efektif dalam menurunkan plak.

\section{Konflik Kepentingan}

Penulis menyatakan tidak terdapat konflik kepentingan dalam studi ini.

\section{DAFTAR PUSTAKA}

1. Departemen Kesehatan Republik Indonesia. Undang Undang Republik Indonesia No 36 Tahun 2009 Tentang Kesehatan. Jakarta; 2009.

2. Malik I. Kesehatan Gigi dan Mulut. Bandung: Unpad, 2008.

3. Sriyono NW. Pengantar ilmu kedokteran gigi pencegahan (Cetakan II). Yogyakarta: Medika Fakultas Kedokteran Universitas Gajah Mada, 2007; p. 22.

4. Kementerian Kesehatan Republik Indonesia. Situasi Kesehatan Gigi dan Mulut. Jakarta; 2019. Available from: https:// www.kemkes.go.id/article/view/20030 900005/situasi-kesehatan-gigi-danmulut-2019.html

5. Sondang P, Hamada T. Menuju gigi dan mulut sehat: Pencegahan dan Pemeliharaan [serial online] 2008 [cited 2020 Oct 1]. Available from: URL: http://usupress. usu.ac.id/files/Menuju\%20Gigi\%20dan 
\%20Mulut\%20Sehat\%20_Pencegahan $\% 20$ dan\%20Pemeliharaan_Normal_a wal.pdf.

6. Limeback H. Comperehensive Preventive Dentistry. Iowa: John Wiley \& Son Ltd, 2012; p. 11-4.

7. Kidd EAM, Joyston-Bechal S. Dasar-dasar Karies Penyakit dan Penanggulangannya. Sumawinata N, Faruk S, alih bahasa. Jakarta: EGC, 1999.

8. Chrismirina S, Tjahajani A, Brotosoetamo S. Pembentukan mikrobial biofilm dalam rongga mulut. IJD 2006;13(1):55-60.

9. American Academy of Pediatric Dentistry. Policy on use of xylitol in pediatric dentistry. The Reference Manual of Pediatric Dentistry. Chicago, Ill.: American Academy of Pediatric Dentistry; 2020:70-1. Available from: https://www.aapd.org/media/policies_g uidelines/p_xylitol.pdf

10. Makinen KK. History, safety, and dental properties of xylitol [serial online] 2000 [cited 2020 Oct 1]. Available from: URL: http://xylitol.org.

11. Wiria F. Pengaruh teh hijau terhadap plak [serial online] 2015 [cited 2020 Oct 2]. Available from: URL: http://lib.ui.ac.id.

12. Ly KA, Milgrom P, Rothen M. The potential of dental propective chewing gum in oral health interventions. JADA. 2008; 139(5):553-63.

13. Fatikarini I, Handajani J. Pengunyahan permen karet gula dan xylitol menurunkan pembentukan plak gigi. Maj Ked Gi. 2011;18(2):11-4.

14. Rahmawati DY. Efektivitas mengunyah permen karet berxylitol untuk mengurangi indeks plak gigi (studi kasus di SDN Sekaran 01 Gunungpati Semarang) [Skripsi]. Semarang: Universitas Negeri Semarang; 2011.

15. Kusumaningsari V, Handajani J. Efek pengunyahan permen karet gula dan xylitol terhadap pertumbuhan bakteri streptococcus mutans pada plak gigi. Maj Ked Gi. 2011;18(1):30-4.

16. Sumantri D. Pengurangan akumulasi plak gigi dengan membandingkan metode mengunyah permen karet xylitol dan berkumur teh hijau. Jurnal Material Kedokteran Gigi. 2013;2(2):174-80.
17. Elina L, Wahyuni S. Pengaruh pengunyahan permen karet yang mengandung sukrosa dan permen karet yang mengandung xylitol terhadap indeks plak gigi. Jurnal Keperawatan Poltekkes Tanjungkarang. 2017;13(1):1-4.

18. Hasibuan UHR. Gambaran mengunyah permen karet yang mengandung xylitol dalam menurunkan indeks plak pada siswa/i kelas V SD Negeri 0507 Latong Kecamatan Lubuk Barumun Kabupaten Padang Lawas [Karya Tulis Ilmiah]. Medan: Politeknik Kesehatan Kemenkes Medan; 2018.

19. Nabila NN. Pengaruh mengunyah permen karet yang mengandung xylitol terhadap pH saliva dan indeks plak pada siswa SLB A (Tunanetra) Negeri Semarang tahun 2019 [Skripsi]. Semarang: Politeknik Kesehatan Kemenkes Semarang; 2019.

20. Kusuma N. Plak gigi. Padang: Andalas University Press, 2016; p. 2-15.

21. Putti FD. Pengaruh mengonsumsi permen karet yang mengandung xylitol terhadap pembentukan plak gigi [Skripsi]. Semarang: Universitas Diponegoro; 2008.

22. Autio JT, Courts FJ. Acceptance of the xylitol chewing gum regimen by pre school children and teachers in a head start program: A pilot study. Pediatr Dent 2001;23(1):71-4.

23. Kandelman D, Gagnon G. Clinical results after 12 months from a study of the incidence and progression of dental caries in relation to consumption of chewinggum containing xylitol in school preventive programs. J Dent Res. 1987;66(8):1407-11. Doi: $10.1177 / 00220345870660082501$.

24. Milgrom P. Xylitol and its vehicles for public health needs. Adv Dent Res. 2009; 21(1):44-7.

25. Akerblom HK, Koivukangas T, Puukka R, Mononen $\mathrm{M}$. The tolerance of increasing amounts of dietary xylitol in children. Int J Vitam Nutr Res Suppl. 1982;22:53-66.

26. Ly KA. Xylitol gummy bear snacks: A school-based randomized clinical trial. BMC Oral Health 2008;8(20):1-11. 